\title{
Overcoming the past and shaping the future: the quest for relevance in teaching and researching public administration in Africa
}

\section{Chris Tapscott ${ }^{1}$ (1)}

Received: 24 October 2021 / Accepted: 10 November 2021 / Published online: 23 November 2021

(c) The Author(s), under exclusive licence to Institute for Global Public Policy, Fudan University 2021

\begin{abstract}
The status of teaching and research on public administration in Africa countries, in many respects, remains a vestige of the colonial era and this is reflected in the epistemologies that underpin the design of the curricula and pedagogies adopted. They have been further shaped by the injunctions of neoliberalism and conditionalities of donor aid which promote normative northern models of public administration. Recognising this reality African scholars and others have, for some time, advocated for transformative models of policy formulation and governance which more accurately reflect African contexts. Commencing with an analysis of the historical factors that shaped state formation and administrative practices in post-colonial Africa, this article broadly examines how public policy and governance are taught and researched in African institutions. It also reflects on the challenges which confront African academics in developing curricula and in conducting research which is relevant to their national contexts. In so doing, it considers ways in which scholars might retain the essence of key theoretical precepts whilst adapting them to local contexts. It also argues for a stronger pan-African focus in the development of teaching materials and in conducting research which traverses linguistic and geographic boundaries.
\end{abstract}

Keywords African colonial state legacies - Conditionalities of neoliberal aid · Comparative public administration · Hegemony of northern policy theory . Contextual governance $\cdot$ Constraints to policy research and teaching $\cdot$ Decolonizing African university syllabi

This paper builds on an earlier version published in Onyango, G. (2021) (ed). Routledge Handbook of Public Policy in Africa, Routledge.

Chris Tapscott

ctapscott@uwc.ac.za

1 School of Government, University of the Western Cape, Cape Town, South Africa 


\section{Introduction}

The legacy of colonial rule and the impacts of neoliberalism (Halvorsen, 2018; Mamdani, 2016; Slaughter \& Rhoades, 2004) continue to have a profound impact on the public policy and governance of most, if not all, African states. These factors also play a significant role in the academic realm, shaping the content and context of teaching and research and leading to a significant degree of isomorphic mimicry in their adherence to theories and methodologies from the global North. In large part, this can be ascribed to the structure of colonial states and to the paths prescribed for them as a conditionality of donor aid in the post-colonial era, paths which have subsequently been validated in the curricula taught in national educational institutions and in the research supported by international funding agencies. From an academic perspective, this has posed challenges of an ontological and epistemological nature, leading to a disconnect between the normative administrative models imparted to students through formal learning programmes and the realities of policy and governance experienced in practice.

This article looks broadly at the historical forces that have shaped state formation and administrative practices in post-colonial Africa and the ways in which neoliberal understandings of policy formulation and governance, embedded in the conditionalities of aid, have reinforced the hegemony of northern thinking about how African states should be governed. The analysis considers how public policy and governance are taught and researched in African institutions and reflects on the challenges which confront African academics in developing curricula and conducting research which is relevant to their national context. In so doing, it considers ways in which scholars might retain the essence of key theoretical precepts and, at the same time, adapt them to local circumstances. It also argues for a stronger pan-African focus in the development of teaching material and in conducting research which traverses linguistic and geographic boundaries.

As point of departure, it is important to begin with a disclaimer, namely that any summative study of administrative policies and practices in Africa runs the risk of presenting the experiences of different African states as if they are in some way homogenous. Not only does such an approach open itself to criticism of superficial generalisation but it also runs the risk of reinforcing stereotypes of what is a highly diverse and fast transforming continent. The exercise is further constrained by linguistic barriers which limit access to important research and academic texts which might add nuance to the analysis of policy and governance systems in different countries. The discussion which follows thus represents no more than a schematic overview of trends in the research and teaching of policy and governance across Africa, with the hope that it will serve as a stimulus to a more extensive analysis in future. 


\section{The enduring legacy of colonialism}

The impact of colonialism and neo-colonialism on the structure of the state and political and social economy of countries across Africa has been discussed exhaustively by an array of eminent scholars (Mazrui, 1977; Nkrumah, 1965; Rodney, 1982, amongst others) to the extent that the subject may now seem passé. Given its enduring legacy, however, it is essential to reference this history when analysing the current trajectory of teaching and research on public policy and governance on the continent.

Notwithstanding some variance in the policies of different powers, the imperialist ambitions of colonialism were concentrated on the extraction of primary resources, the installation of basic infrastructure (railways and ports) to facilitate this, and control of the indigenous population. Due to this limited remit, Chabal and Daloz have argued, colonial states were never formally institutionalised and particularly in the rural areas, where the bulk of the population resided, they assigned considerable discretionary power to local officials and exercised administrative power through the indirect rule of traditional authorities (Chabal \& Daloz, 1999, p. 4). Education in this context was afforded little importance and according to Walter Rodney:

"The main purpose of the colonial school system was to train Africans to help man the local administration at the lowest ranks and to staff capitalist firms owns by Europeans... It was not an educational system designed to give young people confidence and pride as members of African societies, but one which sought to instil a sense of deference towards all that was European and capitalist" (Rodney, 1982, p. 240).

Although there had been faltering steps to promote self-rule in some colonies in the aftermath of World War II (notably by the British), these initiatives, for the most part, envisaged a protracted process with no specific end date (Brookfield, 1975). Consequently, when the decolonisation process began in earnest in the 1960s, most African states were woefully ill-prepared for statehood in terms of their economic development, public institutions, and the number of skilled personnel at their disposal. Furthermore, from a Weberian perspective the colonial state, having never been formally bureaucratised, was not sufficiently emancipated from society to enable the public service to operate independently of the constraints of social pressure and the ties of ethnicity and kinship (Chabal \& Daloz, 1999). This reality, together with the artificial nature of colonial boundaries, presented a serious constraint to nation building in the post-colonial era.

Notwithstanding this stark reality, there was a conviction amongst former colonial powers, the United States, and multi-lateral funding agencies such as the World Bank, that the economic development of African states could be fasttracked in similar fashion to the reconstruction of the war-torn European states post 1945. In this exercise, they were guided by the principles of modernisation, first expounded by the likes of Durkheim and Tonnies but given their contemporary expression by Talcott Parsons (Parsons \& Shils, 1951). Based on trends 
in Europe and North America, the modernisation theorists described what they saw in some states as a form of economic dualism which consisted of an agricultural sector, which was labour intensive and agricultural, and a modern sector, which was capital intensive and industrial. The theories of economic dualism that emerged to describe this phenomenon attempted to combine into one system, principles for the development of an advanced and a backward economy (Brookfield, 1975, p. 58).

The concept of modernisation was most clearly articulated in WW Rostow's The Stages of Economic Growth which became a highly influential text in the development realm following its publication in 1960 (Brookfield, 1975). Basing his assumptions on what he believed to be observable principles of historical development, Rostow identified all countries as falling within one of five categories: "the traditional society, the preconditions for take off, the take off, the drive to maturity, and the age of high mass consumption" (Rostow, 1960, p. 4). He believed that most developing countries fell within the first of these categories and the preconditions for their take-off could be created by a rise in the rate of productive investment (through foreign aid and local savings), the importation of modern technology (to stimulate an industrial revolution), and support for the emergence of a new elite (Rostow, 1960, p. 26). The emphasis on elites formed the basis of the "trickle down" thesis, which supposed that the benefits derived from capital poured into the urban top would logically filter down to the rural roots. The priority attached to the economic development of the cities was based on the belief that the emergence of a motivated minority was essential for the generation of savings and investments necessary to get emerging economies off the ground. Significantly, the need to develop the preconditions for economic growth was a principle widely adopted in aid programmes implemented in Africa throughout the First Development Decade and Rostow and his contemporaries established economics (to the virtual exclusion of other disciplines) as the key to progress in post-colonial states.

In contrast, public administration theory, which at the time had yet to achieve similar prominence in the global North, proceeded according to a positivist logic which viewed policy formulation as a technocratic exercise, best addressed through the application of rational decision-making models. Furthermore, premised on an idealised Weberian principle, policy making was viewed as a process distinct from politics, and hence, primarily the responsibility of public officials (Pollitt \& Bouckaert, 2011, p. 5). Thus, whilst there was talk of the need for 'good government' in African states, this was understood to be the degree to which their policy making and administration systems most closely emulated practices in the former colonial powers (Seidler, 2016, p. 159). The concept of governance, as shall be discussed, had yet to enter the discourse on public administration and policy formulation.

Adding complexity to the process of decolonisation, the transition to independence took place at the height of the ideological struggles of the cold war. In this milieu, newly independent countries in Africa were encouraged to adopt models of economic development administration advanced by Western states (and, to a lesser extent, by the former Soviet Union and Communist Bloc), and indeed, this was generally a precondition for the receipt of foreign aid. In this context, it should perhaps come as no surprise that Rostow's Stages of Economic Growth was subtitled "a 
non-communist manifesto". During this period allegiance to the West and a commitment to capitalism, took precedence over concerns about democracy, autocratic rule, and even corruption. As a result of this, and the desire to maintain their sphere of political and economic influence, former colonial powers and other Western states continued to support despotic leaders such as Mobutu in the Congo, Eyadéma in Togo, and Bokassa in the Central African Republic throughout the first 2 decades of the post-colonial era and beyond.

Notwithstanding increased technical and financial assistance from the global North from the 1960s onwards, however, post-colonial governments in Africa struggled to develop effective public services and were equally unsuccessful in addressing the multiple challenges of statehood and nation building which they had inherited from their colonial masters. In many respects, as Chabal and Daloz have pointed out, this was to be expected since the existence of a Weberian bureaucratic state in colonial Africa, was "essentially a myth of the colonial mission and there was never much chance it would survive at independence" (Chabal \& Daloz, 1999, p. 12). The reasons for these shortcomings were multiple and included unequal terms of trade, poor infrastructure, weak institutions, underdeveloped economies, a limited pool of skilled officials, inter-ethnic struggles (accentuated by the divide-and-rule strategies of colonial rule), and elite corruption. This is not to ignore the agency of African leaders in the process or to condone corrupt and authoritarian rule, but rather to suggest that the structure and form of post-colonial states provided an enabling environment for this to happen.

By the late 1970s, confronted with a succession of coups, failing states, weak economic growth and limited poverty reduction, multi-lateral and bi-lateral development agencies began pushing for reform of the administrative systems they had hitherto promoted in states across the continent. As had been the case in the immediate post-colonial era, the focus of these reforms was, in the first instance, on the economy and this tracked neoliberal trends in the North. The most far reaching of the reforms imposed as a conditionality of aid were the Structural Adjustment Programmes (SAPs) which entailed downsizing of the state and the reduction of government expenditure amongst other measures intended to introduce tighter fiscal control and promote economic stability. As the literature reveals, the SAPs and subsequently New Public Management (NPM), did little to stimulate economic growth and, in many instances, aggravated poverty (Manning, 2001; Mutahaba \& Kiragu, 2002; Olowu, 1999). Furthermore, as the cold war subsided and the influence of the Soviet bloc in Africa waned in the 1980s, the attention of international funding agencies and donors shifted to the need for greater political accountability and more effective governance in the states they were assisting. In so doing, what had been viewed as the technocratic process of policy formulation was now seen to include the need for the rule of law, transparency, efficiency and effectiveness, equity, and strategic visioning, amongst other variables of good governance (United Nations Development Programme, 1999). Henceforth, policy formulation in Africa was seen to form part of the exercise of 'good governance', but once again, this was premised on the idea that this should replicate 'best practices' in economically advanced states in the North. Considerably less thought was given to the development of administrative models which might better suit the context of developing states on the 
continent. In this environment, prospects for the emergence of indigenous forms of public administration theory in the post-colonial era were by no means propitious.

\section{The enduring hegemony of Northern theory}

Over the course of the past 2 decades, multiple scholars have emphasised the disjuncture between the policies prescribed as a conditionality of aid (and validated in public administration theory), and the socio-cultural, political, and economic realities confronted by African administrators on the ground. The source of this disjuncture, Amoah has argued, is an ontological one since "public administration, as theorized and practiced at present does not actively take into account, and indeed ignores, the African worldview". This situation, he asserts, "is undoubtedly the product of Euro-American ontological grounding with its universalizing, totalizing, and hegemonic orientation" (Amoah, 2012, p. 397). Notwithstanding the implicit universalising in Amoah's own projection of an all-embracing African ontology, it is not in dispute that the orthodox literature on public policy studied in the global South has its roots in Northern theory and ways of thinking and this continues to infuse and shape academic thinking in African states. Furthermore, it remains a truism, certainly in the Anglophone world, that administrative theory (and certainly the most influential) is derived from experience in the global North. Where theoretical attention has focussed on transitional states, their activities, and typically their shortcomings, are all too often analysed in terms of their deviation from accepted norms in the North. This is not to suggest that Northern theorising is irrelevant to the South, much clearly retains universal validity, however, the normative bent of much of the theory continues to be inherently ahistorical and apolitical, and largely ignores the complexity of transitional states in Africa, Latin America and elsewhere. In that regard, as is so often the case, the latent weaknesses of meta-theory in the social and political sciences remains the fact that it is lacks empirical validation across different social, political, and historical contexts.

There is, in practice, a hermetic dimension to public administration theorising. Even the most cursory review of top public administration journals in North America and Europe will, with several notable exceptions, reveal that most articles published deal with issues pertaining in the global North (Hou et al., 2011). ${ }^{1}$ Issues relating to the public sector in states elsewhere in the world, in contrast, although comprising close to three quarters of the global population receive only passing mention. It is also the case that by the time contemporary theories and models of public administration have filtered down from Europe and the United States to African states, they are often on the way out in the countries from which they originated. This was with the case with modernisation theory, NPM and other best practices models but it is also evident in the evident in the pedagogy of public administration taught in the North. Commenting on the status of public administration teaching

\footnotetext{
1 A notable exception in this respect is the increasing number of articles published by Chinese scholars, reflecting the growing influence of China on the global geo-political order.
} 
in British institutions, once international leaders in the field, Talbot asserts that the "subject in its own right is almost moribund". He asserts that " $(\mathrm{t})$ here are a few Masters in Public Administration (MPAs) and in Public Policy (MPPs) in the UK but they mostly cater for the thriving international market, which has expanded hugely in the past two to three decades. There are no longer any undergraduate courses in Public Administration, as there were in the 1970s and ' $80 \mathrm{~s}$ - just the odd module here and there on other courses" (Talbot, 2020).

The disconnect between theory and praxis of public policy is most explicit in the concept of governance, now understood to form an integral part of policy formulation and implementation. The idea of good governance rose to prominence in the developing domain following the publication of a World Bank report in the late $1980 \mathrm{~s}^{2}$ which specified what it believed were the reasons why African states were mismanaged, their economies were failing, and poverty was growing (World Bank, 1989). Following this analysis, the shortcomings of Africans state were ascribed to weak institutions, bloated and ineffective bureaucracies, weak or nonexistent regulatory systems, corruption, and a lack of political accountability. From that point on, improvements in governance systems became a conditionality of aid. As Mkandawire has observed, the term 'governance' has become a mantra in the development business which is presented as a new truth which "must be hammered into the benighted minds of African policy makers. The Africans themselves", he maintains, "often consider it as one more item on the list of aid conditionalities." (Mkandawire, 2007, p. 679).

As with the imposition of previous models, however, good governance has all too often been portrayed as a normative end state to which developing countries must aspire and their progress towards to this goal is measured against a Northern ideal and a predetermined set of indicators. Missing from much of the analysis is discussion of how long it took Northern states to reach this ideal state of governance, that they had no normative goal of good governance to which they were striving, and that they took many paths in their quest to improve public sector performance. Commenting on this Chabal and Daloz assert that "the most cursory examination of the history of the modern Western state would have shown that it did not develop because it was 'programmed' to do so. It was constituted over time in the form we know today because of a very specific, and probably unique, configuration of economic and socio-political dynamics" (Chabal \& Daloz, 1999, p. 14). The conventional understanding of good governance is thus, in effect, a retrospective one that includes an ensemble of different measures adopted by different players at different times. Furthermore, as research by a number of scholars has shown (Brinkerhoff \& Goldsmith, 2005; Goldsmith, 2007; Grindle, 2004), not all criteria now specified as preconditions for good governance were followed by Northern states.

The limited successes of what has been termed "the good governance agenda" over the course of the past 2 decades, has prompted various revisionist studies which critically assess the premises on which the notion of governance is based.

\footnotetext{
${ }^{2}$ Given its current prominence in the policy domain, it is surprising how recently the idea of governance entered the realm of public debate, having first surfaced as a distinct concept in the late 1970s and 1980s.
} 
In this vein, Brinkerhoff and Goldsmith have argued that most developing states suffer from what they term institutional dualism. That is a disjuncture between the formalistic elements of good governance (which include strong institutional oversight mechanism) and pre-existing and deeply embedded cultural and administrative practices which shape the way in which the public sector is run (Brinkerhoff \& Goldsmith, 2005, p. 200). They maintain that whilst certain elements of traditional practice such as ineffective service delivery, weak economic competitiveness and limited democratic participation and accountability are responsible for a range of ills in developing and former socialist countries, not all informal governance systems produce negative outcomes and many are better suited to the prevailing socio-cultural system. They argue that the distinction between good and bad governance in this context represents something of a false dichotomy.

Expanding on this theme, Olivier de Sardan asserts that in the extensive literature on the state and public administration in Africa there is a broad concurrence that "the legislation and regulations, procedures, specifications and organizational structures - all of which have largely been patterned on Western models - are rarely adhered to, in either the letter or the spirit, by either the state employees or the service users" (Olivier de Sardan, 2015, p. 1). In this context, he distinguishes between what might be considered professional norms and practical norms. Practical norms he describes as the "informal rules, tacit or latent, that underpin those practices of public actors which do not conform to formal professional and bureaucratic norms. They describe the extent to which these practices converge, and they allow us to understand the divergences or 'play' (the 'slack', as it were) between formal norms and practices" (Olivier de Sardan, 2014, p. 408). Whilst these norms may never formally be expressed, they nevertheless are widely understood and contribute to what he describes as the regulated informality that exists within African bureaucracies. Whilst acknowledging gradation in these practical norms, ranging from those which speed up bureaucratic red tape to outright extortion, in their more benign forms, he maintains, they can bring surety to citizen engagements which public officials.

Other scholars have argued for an approach that takes account of the socio-cultural and political realities of developing states and the fact that it is not possible, nor indeed desirable, to try to emulate Northern models of governance. Writers such as Grindle have suggested the need for what she has termed "good enough governance" which focuses on a few key aspects of governance which might feasibly be achieved within the political and administrative realities of a developing state (Grindle, 2004). In a more radical take, Booth suggests that need to "go with the grain" rather than to "swim against the tide". He suggests that there are dominant patrimonial practices in many if not most African states and elaborate systems of clientelism and patronage which are deeply embedded in society and which will not easily be supplanted (Booth, 2011). He suggests working with these systems rather than against them in a progressive process of change, supporting practices which lead to better service delivery and accountability and ignoring those that do not. In a stern critique of the governance reforms imposed on states in Africa, Booth and Cammack assert that "We should stop judging the appropriateness of institutions and proposing governance reforms on the basis of weak theory about the causal 
linkages between political institutions, especially democratic ones, and development outcomes" (Booth \& Cammack, 2013, p. 10).

To better understand these processes, Lavigne Delville and Ayipam call for a closer interaction between those studying public policy and social anthropologists, who can provide insight into the historical, socio-cultural, and political contexts which shape the ways in which decision making takes place in the public sector. "It is", they maintain, "a question of looking into the relationships between the various actors who define and implement the response to public and collective problems, by seriously taking into account the links between policies, politics and polities as well as the relatively low degree of institutionalization-resulting from a strong political influence on organizations and a high personalization of their agents' practices - and extraversion strategies" (Lavigne Delville \& Ayipam, 2018, p. 8). Such an approach does not represent a call for cultural or national relativism which recognises no common or normative dimensions of governance but proposes that local contexts need to be taken seriously in the analysis of policy processes in African states.

\section{Teaching public policy and governance in Africa}

Due to the precipitous way in which decolonisation took place in Africa in the 1960s and 1970s and the fact that the education of the indigenous population had never been a priority for colonial powers, few countries had the educational institutions ${ }^{3}$ and personnel necessary to support the process of nation building and economic development. As a result, most remained heavily reliant on educators from former colonial powers as well as those seconded by countries in the global North sympathetic to the newly independent states. In the case of public administration, this meant that there was a continuity in the curricula and pedagogy of academic programmes, if these even existed, and in the training provided to public officials. At the same time, a select group of young academics and officials were given scholarships to further their studies in Northern states. In a minority of states which had embraced socialism (such as Tanzania and Mozambique), officials were also sent to countries in the Soviet bloc for their training. In former Francophone colonies the training of public officials was, and in many instances still is, based on the model of the French Ecole Nationale d'Administration which provides specialist, and elite, training to current and prospective senior civil servants. The net effect of this was that teaching and training of public administration in the aftermath of decolonisation continued to track trends in the global North and was framed within the dominant theoretical paradigms of the time, in a trend which continues to this day.

There is considerable variance in the way in which policy and governance in tertiary education institutions is taught and researched both within and between African states but, once again, this is influenced more by the legacy of their colonial past (British, French, Portuguese, Belgian, etc.) than by the emergence of indigenous

\footnotetext{
3 According to Mamdani at the outset of the 1960s the whole of East Africa had just one university (Mamdani, 2016:111).
} 
epistemologies of public administration. In their stead, forms of institutional isomorphism have emerged which reinforce adherence to common standards or perceived best practices in the former colonising countries and in the North more broadly. This perspective, Koch and Weingart argue, is reinforced by the emergence of a global network of professionals which amounts to an epistemic community. Although the members of this network may come from different disciplines, they maintain, "they share a set of normative and causal beliefs, notions of validity and a common policy enterprise" (Koch \& Weingart, 2016, p. 66). In other words, a common understanding of the causality of problems and how they should be resolved.

A cursory review of post-graduate public administration curricula at universities in select Anglophone countries in Africa, for example, reveals that, some local content notwithstanding, most are bench-marked against what might be considered normative offerings in the United States, United Kingdom, Australia, and other English-speaking countries. This has been aggravated by the growing global commodification of tertiary education advanced by the nostrums of neoliberalism, the totalising effect of which is a source of concern in academic communities throughout the world. The increasing privatisation of universities, in particular, has meant that access to tertiary education is more than ever determined by affordability, and hence by class. The proliferation of on-line courses offered internationally by universities in the global North has also reinforced the notion that academic programmes are value neutral and hence may unproblematically be transferred from one country to another. In as much as there is some convergence between the graduate and postgraduate programmes on offer in African countries and those in the global North, this is an asymmetrical one that reinforces normative Northern understandings of public policy and governance rather than one which incorporates the experience of public administrators in African states.

The totalising threat of globalisation and the growing commercialisation of tertiary education, nevertheless, has also reinvigorated long standing calls by scholars for the decolonisation of African education, and for the development of curricula informed by indigenous ontologies and epistemologies, and no more so than in the field of public administration. However, much as there is consensus on the need for transformation of public administration as a subject, there is considerably less certainty on how this is to be achieved. In part, this is due to a lack of conceptual clarity on what needs to be transformed and in part to the lack a strategic programme of action to address the challenge.

In some conceptualisations, scholars have been drawn towards a form of millennialism that harkens back to a past ordered by "original African values and culture" (Matsiliza, 2020, p. 296) and which proposes that the "re-founding the administrative systems based on African values is likely to be the answer to the development challenges bewildering the continent" (Basheka, 2015, p. 481). Mbembe, however, cautions against confusing the process of decolonialisation with that of Africanisation which he views as an ideological project which, of necessity, occurred as part of the process of nation building in the immediate post-colonial era (Mbembe, 2016). Citing Fanon, he maintains that this version of Africanisation was appropriated by new ruling elites and reproduced in forms of narrow nationalism to the extent that it became an "ideology masking what fundamentally was a 'racketeering' or predatory 
project—what we call today 'looting"' (Mbembe, 2016, p. 33). In its place he calls for a more emancipatory form of decolonisation which seeks not only to recentre African identity in African education, but which also challenges the growing hegemony of global elites and imagines a more inclusive social order. Rather than the exclusivity of conventional Northern university education, which he perceives to be founded on strict and exclusory disciplinary boundaries, Mbembe advocates for what has been termed a pluriversity:

"By pluriversity, many understand a process of knowledge production that is open to epistemic diversity. It is a process that does not necessarily abandon the notion of universal knowledge for humanity, but which embraces it via a horizontal strategy of openness to dialogue among different epistemic traditions. To decolonize the university is to therefore to reform it with the aim of creating a less provincial and more open critical cosmopolitan pluriversalism-a task that involves the radical refounding of our ways of thinking and a transcendence of our disciplinary divisions" (Mbembe 2016, p. 37).

The intellectual task envisioned by Mbembe is considerable and he warns that "if we do not develop a complex understanding of the nature of what we are actually facing, we will end up with the same old techno-bureaucratic fixes that have led us, in the first place, to the current cul-de-sac" (Mbembe, 2016, p. 31). The conceptualisation and development of a more Afrocentric version of public administration, however, will necessitate a prolonged and concerted intellectual process involving academics from across the continent, from those within the African diaspora, as well as non-African scholars sympathetic to the cause.

Before enjoining battle, however, it will be essential to know the strengths and weakness of the epistemologies which will need to be adapted or changed. This will entail a critical analysis of the theoretical paradigms and models which constitute the current mainstream of orthodox public administration and assessment of the extent to which they might have explanatory and predictive power in African contexts. Here, it is understood, in an increasingly interconnected world with extensive interpersonal transactions and high levels of international mobility, that such an exercise will not imply a wholesale rejection of existing theory but rather the adaptation and broadening of its scope to local circumstances. Principal-agent theory, for example, clearly has some universally explicatory relevance but in an African context, where patrimonial relations often penetrate public institutions, the categorisation of who is a principal and who is an agent could differ significantly from conventional understandings of the concepts. What is called for is the type of critical analysis conducted by Ayee in his assessment of the relevance of such key conceptual frameworks as agency theory, transaction theory, and public choice theory in an analysis of public sector reform in African countries. By carefully examining the core tenets of these theories, he identified those elements which he considered to have explanatory and predictive power and those which did not (Ayee, 2008). Regrettably, Ayee stopped short of proposing alternatives to these theoretical frameworks or suggesting ways in which they might be adapted to better explain trends in African states.

Broadening the case base to include experiences from Africa and elsewhere in the developing world would unquestionably be of benefit to public administration 
theory more broadly, testing the extent to which the premises of theoretical models based on Northern experience have explanatory or predictive value in the global South. Through this process, for example, it might transpire that theory recognised for its relevance in the North has little explanatory power in African contexts and vice versa. Over and above the need to deconstruct and reassess the relevance of orthodox theory, however, there is a need to move away from a narrow technocratic focus on organisational structure, administrative systems, and managerialism and to expand the academic ambit of public administration analysis to include the sociocultural, political, economic, and geo-political contexts in which state institutions operate and in which policy is formulated and implemented. In that respect, it is axiomatic that the quest to develop more Afrocentric epistemologies of policy and governance will need to be under-pinned by vigorous research and herein lies a further, although not insurmountable, challenge.

\section{The limited research base of public administration in Africa}

Despite the recognised need to maintain a virtuous circle between research and teaching, academics in many tertiary institutions in Africa struggle both to conduct research on public policy and governance and to publish their findings. This may be ascribed to a number of factors including heavy teaching loads (Felde et al, 2021, p. 58), a lack of mentorship, and especially a shortage of research funding. Illustrative of this, in a study published in 2017, Kasozi reported that Ugandan universities allocated no more than $5 \%$ of their annual institutional budget to research and, consequently, they were unable to fulfil "their multiple functions of research, innovation, training and public service" (Kasozi, 2017, p. 1). This deficit he attributed to the governance of universities and to the fact that "most stakeholders, including the controllers of the state, administrators, university managers, academic staff, parents and the general public see the major function of universities as training for the labour market" (Kasozi, 2017, p. 2). In that respect, as Cloete et al. point out, the role envisaged for universities in Africa often includes two contradictory notions, the first an instrumentalist one (as a service provider producing skilled personnel) and the second that of an 'engine of development' (aimed at knowledge production and innovation) (Cloete et al., 2015, p. 19). In resource constrained institutions, they maintain, it is the instrumentalist focus which prevails and this inhibits innovation and the quest for indigenous solutions to local problems.

At the same time, notwithstanding the fact that governing elites may, justifiably, decry the imposition of foreign models of policy making and governance, they express considerably less interest in funding research which might support the development of indigenous theories and models as an alternative to the hegemony of Northern thinking (Felde et al, 2021, p. 58). As a result, with a few notable exceptions, academics across Africa struggle to gain access to research funding and although this is a constraint facing all disciplines it is especially challenging in the social sciences which encompasses politics and public administration. In part, this is due to the preponderance of support from donor agencies for research relating to health, agriculture, information technology, climate change, 
and other science-based topics. It is also because governments, themselves, are reluctant to support research which might expose weakness in their own administrative and regulatory oversight systems (Hydén, 2016, p. 25). There is, consequently, limited national funding available to undertake either in-country research or comparative research across other African countries on issues relating to public policy and governance. Although some international donor agencies do support both bi-lateral and multi-lateral research in this realm, the scope is generally limited to one or two countries. There is also irony in the fact that comparative studies intended to advance new epistemic communities in the global South typically only advance when funded, and anchored, through the solidarity of research partners in the North.

In addition to funding shortages, African scholars confront a range of operational challenges if they do attempt to undertake empirical research on public policy and governance. Gaining access to public institutions is tightly regulated in many states and limitations are set on the types of investigations which are permissible and information which may be reported on. Post-graduate students, for example, are frequently required to apply for permits which prescribe where, when, and what type of research they may undertake. There is also the danger of speaking truth to power in a context where scholars are reliant on state sponsored grants or, more commonly, are employed in state funded universities. In this context there are fears, whether real or imagined, that research which is 'sensitive' or too critical of the failures of public policy (and particularly that which exposes political corruption) could lead to various forms of censure, including a loss of employment or prosecution (Taha \& Bjørkelo, 2016, p. 226). Whilst threats of this nature emanate primarily from the state, the management of research institutes themselves may encourage self-censure by researchers for fear of raising the ire of governing elites or of jeopardising access to state funding (Kasozi, 2017, p. 4).

Further constraints relate to the problems which confront researchers in accessing relevant and current literature. Whilst access to on-line journals and other data bases holds the potential to alleviate this problem, it remains a reality than many African universities cannot afford a full bouquet of on-line journals and e-books, their range is limited, and those that are available are often dated. A further limitation is imposed by the system of university ranking, yet another imported product of globalisation, which promotes competition between institutions and acts a disincentive to collaborative research. As consequence, there is limited potential to build up a critical mass of scholars working on related themes and research becomes atomised in isolated teaching departments and centres. Where this occurs, it can negatively impact the advancement of young academics who need broader exposure to the field, both to expand their knowledge of current trends in the discipline and to build their confidence.

The fact that so little research is being undertaken, also has a limiting effect on the knowledge of lecturers and their ability to make real the subject matter they are teaching. A lack of exposure to the practicalities of the public sector operations reduces the prospect for the use of case studies to illustrate the way in which states function administratively. It also limits prospects for critical analysis of the modes of policy formulation and governance pursued both within and between different states 
and increases the likelihood that lecturers will fall back on orthodox public administration texts in the design of their own teaching courses.

Paradoxically, notwithstanding the disruption and suffering which it has wrought, the advent of the Covid-19 pandemic has pointed to ways in which African scholars might circumvent some of the challenges faced when attempting to conduct comparative studies of public policy and governance in states across the continent. The use of on-line platforms during national lockdowns has demonstrated how academic activities, including research, may be conducted virtually and need no longer be constrained by the cost of travel both within and between states on the continent. Here, the solidarity of Northern partners could come into play, providing support for the strengthening of digital platforms and increasing access to free and open-source literature. It goes without saying, however, that ultimate responsibility for conducting research and the development of new epistemologies and new curricula rests with African scholars themselves and that in this undertaking, it is certain, they cannot operate alone.

\section{Conclusion}

The status of teaching and research on public policy and governance in Africa remains a vestige of the colonial era and the increasing influence of neoliberalism and globalisation, each of which influence the epistemologies that underpin the design of curricula taught and the pedagogies adopted in teaching public administration. Recognising this reality African scholars and others have, for some time, advocated for forms of policy formulation and governance which more accurately reflect African socio-cultural contexts. Notwithstanding despondency in some quarters that there has been relatively little progress towards this goal, Amoah makes the important point that "vital discursive space has been opened up by the realization in the public administration literature that the dominant, hegemonic, positivist ontology that has undergirded public administration as a discipline and practice all along cannot cover the entire spectrum of approaches to reality" (Amoah, 2012, p. 395). However, whilst there is widespread acceptance amongst African academics and students alike on the need to recentre public administration teaching and research, the mere stating of this need will not bring about the necessary change. Current writing on the topic, important as this has been, has been discursive and the ensuing debate has been both diffuse and unsupported by empirical research. ${ }^{4}$

What is called for is a concerted, collaborative effort across institutions both within and between countries across the African continent. As Mbembe reminds us: "Decolonizing an African university requires a geographical imagination that extends well beyond the confines of the nation-state" (Mbembe, 2016, p. 36). This will require the development of a broad research agenda by public administration scholars throughout Africa and the establishment of epistemic communities which

\footnotetext{
4 It must be noted that the Journal of Public Administration in South Africa, in particular, has encouraged debate on the subject and has provided a platform for scholars interested in the topic.
} 
look at different facets of the challenge facing teaching and research in the field of policy and governance. In that respect, such an initiative should also aim to build the confidence of young African scholars that the ontology and epistemological frameworks adopted in their teaching and research are sui generis and hence as valid those taught in states in the global North.

An exercise of this nature and scale cannot be undertaken as quick fix, but as an ongoing process which aims to address the legacy of the past and, at the same time, to develop forms of public administration scholarship appropriate to positioning African states in the new global order. As a point of departure, this initiative will require a more decisive role in mobilising scholars by regional and continental bodies such as the African Association for Public Administration and Management (AAPAM), the Association of Southern African Schools and Departments of Public Administration and Management (ASSADPAM), and the South African Association of Public Administration and Management (SAAPAM) amongst other such structures. Whilst the establishment of collaboration of this type might in the first instance be virtual, it is likely to gain publicity and further support with the publication of innovative research.

It will also be necessary to combine initiatives to recentre African public administration with ongoing initiatives to decolonise education and knowledge in Africa more broadly. In this way, it will be possible to draw on the important work already underway in a number of research and teaching institutions across Africa, including the Makerere Institute of Social Research (MISR) in Uganda, the Council for the Development of Social Science Research in Africa (CODESRIA) in Senegal, Laboratoire d'Etudes et de Recherche sur les Dynamiques Sociales et le Développement Local (LASDEL) in Benin, and in a number of universities and research institutes in South Africa. To date, however, efforts in this direction have been disjointed. Further support can be elicited from sympathetic funding agencies and academic institutions in the North, many of which have come to recognise the importance of building research linkages with partners in the South and the need to expose their students to alternative ways of thinking about global challenges. It is essential, however, that the agendas set by such partnerships are developed collaboratively and accurately reflect the research priorities of African academics, a process which did not always occur in the past.

In the final analysis, it should be understood by all participants that the ultimate goal of this undertaking will be to support the development of forms of public policy formulation and governance which be of relevance to African states and which will ultimately lead to improvement in the livelihoods of people across the continent.

(Halvorsen, 2018; Mamdani, 2016; Slaughter \& Rhoades, 2004).

\section{Declaration}

Conflict of interest The author declares that there is no conflict of interest in the publication of this article. 


\section{References}

Amoah, L. G. A. (2012). Constructing a new public administration in Africa. Administrative Theory \& Praxis, 34(3), 385-406.

Ayee, J. R. A. (2008). Reforming the African public sector: Retrospect and prospects. CODESRIA

Basheka, B. C. (2015). Indigenous Africa's governance architecture: A need for African public administration theory? Journal of Public Administration, 50(3), 466-484.

Booth, D. (2011). Working with the grain and swimming against the tide, Africa power and politics, Working Paper 18, ODI, London.

Booth, D., \& Cammack, D. (2013). Governance for development in Africa. Zed Books.

Brinkerhoff, D. W., \& Goldsmith, A. A. (2005). Institutional dualism and development: A revisionist interpretation of good governance. Administration \& Society, 37(2), 199-224.

Brookfield, H. (1975). Interdependent development. Methuen \& Co.

Chabal, P., \& Daloz, J.-P. (1999). Africa works: Disorder as political instrument. Indiana University Press.

Cloete, N., Bunting, I., \& Maassen, P. (2015). Research universities in Africa: An empirical overview of eight flagship universities. In N. Cloete, P. Maassen, \& T. Bailey (Eds.), Knowledge production and contradictory functions in African higher education (Vol. 1, pp. 18-31). African Minds Higher Education Dynamics Series.

Olivier de Sardan, J.-P. (2014). The delivery state in Africa. Interface bureaucrats, professional cultures and the bureaucratic mode of governance. In T. Bierschenk \& J.-P. Olivier de Sardan (Eds.), States at work: Dynamics of African bureaucracies (pp. 399-429). Brill.

Olivier de Sardan, J.-P. (2015). Practical norms: Informal regulations within public bureaucracies (in Africa and beyond). In T. De Herdt, \& J.-P. Olivier de Sardan (Eds.), Real governance and practical norms in Sub-Saharan Africa: The game of the rules (1st edn, pp. 19-62). Routledge.

Lavigne Delville, P., \& Ayimpam, S. (2018). Public policy and public action in Africa, between practical norms, political dynamics and outside influences. Anthropologie \& Développement, 48-49, 7-23.

Felde, A., Halvorsen, T., Myrtveit, A., \& Øygard, R. (2021). Democracy and the discourse on relevance within the academic profession at Makerere University. African Minds.

Goldsmith, A. A. (2007). Is governance reform a catalyst for development? Governance, 20(2), 165-186.

Grindle, M. S. (2004). Good enough governance: Poverty reduction and reform in developing countries. Governance, 17(4), 525-548.

Halvorsen, T. (2018). Democratic developmental state or competition state? Toward the new constitution of neoliberal hegemony. In C. Tapscott, T. Halvorsen, \& T. Cruz-Del Rosario (Eds.), The democratic development state: North-South perspectives (pp. 207-228). Ibidem Verlag.

Hou, Y., Ni, A. Y., Poocharoen, O., Yang, K., \& Zhao, Z. J. (2011). The case for public administration with a global perspective. Journal of Public Administration Research and Theory, 21(suppl_1), i45-i51.

Hydén, G. (2016). The role and impact of funding agencies on higher education and research for development. In T. Halvorsen \& J. Nossum (Eds.), North-South Knowledge Networks (pp. 1-40). African Minds.

Kasozi, A. (2017, July 31). The Impact of Governance on Research in Ugandan Universities. Makerere Institute of Social Research. Retrieved November 20, 2021, from https://misr.mak.ac.ug/publication/ the-impact-of-governance-on-research-in-ugandan-universities.

Koch, S., \& Weingart, P. (2016). The delusion of knowledge transfer: The impact of foreign aid experts on policy-making in South Africa and Tanzania. African Minds.

Mamdani, M. (2016). Undoing the effects of neoliberal reform: The experience of Uganda's Makerere Institute of Social Research. In T. Halvorsen \& J. Nossum (Eds.), North-South Knowledge Networks (pp. 109-134). African Minds.

Manning, N. (2001). The legacy of the New Public Management in developing countries. International Review of Administrative Sciences, 67(2), 297-312.

Matsiliza, N. S. (2020). Decolonisation in the field of public administration: The responsiveness of the scholarship of teaching and learning. Teaching Public Administration, 38(3), 295-312.

Mazrui, A. A. (1977). Africa's international relations: The diplomacy of dependence and change. Heinemann.

Mbembe, A. J. (2016). Decolonizing the university: New directions. Arts and Humanities in Higher Education, 15(1), 29-45. 
Mkandawire, T. (2007). 'Good governance': The itinerary of an idea. Development in Practice, 17(4-5), $679-681$.

Mutahaba, G., \& Kiragu, K. (2002). Lessons of international and African perspectives on public service reform: Examples from five African countries. Africa Development: a Quarterly Journal of CODESRIA, 27, 48-75.

Nkrumah, K. (1965). Neo-colonialism: The last stage of imperialism. Panaf Books Ltd.

Olowu, B. (1999). Redesigning African civil service reforms. Journal of Modern African Studies, 37(1), $1-23$.

Parsons, T., \& Shils, E. A. (1951). Towards a general theory of action. Harvard University Press.

Pollitt, C., \& Bouckaert, G. (2011). Public management reform: A comparative analysis. Oxford University Press.

Rodney, W. (1982). How Europe underdeveloped Africa. Howard University Press.

Rostow, W. W. (1960). The stages of economic growth. Cambridge University Press.

Seidler, V. (2016). Colonial bureaucrats, institutional transplants, and development in the 20th century. Administory, 1(1), 155-172.

Slaughter, S., \& Rhoades, G. (2004). Academic capitalism and the new economy. Johns Hopkins University Press.

Taha, F., \& Bjørkelo, A. (2016). The crisis of higher education in Sudan with special reference to the University of Khartoum, 1956-2014. In T. Halvorsen \& J. Nossum (Eds.), North-South Knowledge Networks (pp. 203-238). African Minds.

Talbot, C. (2020, August 06). From public administration to new public management: Who killed the study of public administration in the UK?. British Politics and Policy at LSE. Retrieved November 20, 2021, from https://blogs.lse.ac.uk/politicsandpolicy/public-administration-uk/.

United Nations Development Programme. (1999). Governance for sustainable human development. UNDP. Retrieved November 20, 2021, from https://digitallibrary.un.org/record/3831662.

World Bank. (1989). Sub-Saharan Africa: From crisis to sustainable growth: A long-term perspective study. World Bank. Retrieved November 20, 2021, from https://documents1.worldbank.org/curated/ en/498241468742846138/pdf/multi0page.pdf. 